\title{
СУСПІЛЬНІ РЕФОРМИ В ІНТЕРНЕТ-ВИДАННЯХ ТЕРНОПОЛЯ «ТЕРЕН» І «20 ХВИЛИН»: МЕДИЧНА ТА ОСВІТНЯ ТЕМАТИКА
}

\author{
Оксана Кушнір \\ Тернопільський національний педагогічний університет імені Володимира Гнатюка \\ вул. Максима Кривоноса, 2, 46027, Тернопіль, Україна \\ e-mail: oksanakush8@gmail.com \\ https://orcid.org/0000-0003-3201-5285
}

У статті обгрунтовано роль медіа у процесі впровадження медичної та освітньої реформ, виділено ключові моменти якісної медіації суспільних процесів. Виокремлено ключові тематичні блоки публікацій про медичну та освітню реформи в онлайн-виданнях Тернополя «Терен» $\mathrm{i}$ «20 хвилин». Окреслено вагомі аспекти реформування медицини та освіти, презентовані на регіональних інтернет-порталах, визначено основні джерела інформації для матеріалів. Результати праці важливі для подальшого дослідження рівня та якості висвітлення медичної та освітньої реформ у медіадискурсі.

Ключові слова: суспільні реформи, медицина, освіта, онлайн-видання, регіональні медіа, тематика.

Вступ. Розбудова української держави та громадянського суспільства, демократична європейська перспектива та активне долучення до світового науково-технічного та культурного прогресу визначили необхідність реформування основних соціальних галузей, зокрема медичної та освітньої.

Для впровадження будь-якої суспільної реформи необхідне належне інформування про неї громадськості засобами масової інформації. Важливу роль у цьому відіграють регіональні медіа, які забезпечують інформаційний супровід реформ на місцевому рівні. Українці часто черпають інформацію із регіональних 3MI, зокрема інтернет-видань, які розглядають глобальні проблеми на локальному рівні, демонструючи їх наслідки безпосередньо для реципієнта, і стають важливим посередником, комунікатором між владою та громадянами. Відтак, актуальність дослідження зумовлена посиленням інтересу суспільства до секторальних реформ $\mathrm{i}$ зростанням ролі регіональних медіа у висвітленні їхнього впровадження.

Мета дослідження полягає в окресленні тематичного діапазону публікацій про медичну та освітню реформи у тернопільських інтернет-виданнях «Терен» [3] $\mathrm{i}$ «20 хвилин» [2], що дозволить на основі індивідуальних характеристик сформулювати універсальні принципи презентування суспільних реформ у регіональному онлайн-просторі.

(C) Кушнір О., 2019 
Методологічну основу дослідження формують праці А. Боневоленської, І. Недопитанського, 3. Меджидової, І. Нікберга, В. Деларю, В. Мартиросяна, Н. Литвиненко, предметом вивчення яких $є$ різні аспекти медичної галузі. Причини виникнення та становлення педагогічної журналістики, ï функції та жанрові особливості, вимоги до журналістів, які пишуть на освітню тему, висвітлювали Т. Денисович та П. Катеринич. Теоретичну парадигму вивчення медійного супроводу медичної та освітньої реформ творять медіатренери, практикуючі журналісти, експерти, учасники медичних та освітніх проектів, журналістикознавці, освітяни, медики (В. Іванов, А. Юричко, А. Романюк, Н. Войтович, Г. Усатенко, О. Рябчук, С. Гончар, О. Голуб та ін.), які у форматі медіашкіл, семінарів, тренінгів, круглих столів намагаються роз'яснити ключові моменти секторальних реформ та роль медіа у процесі втілення якісних та перспективних змін у медичній та освітній галузях. Корисні поради для журналістів пропонують I. Чулівська [9] та авторський колектив посібника «Міфи та правда про освітню та медичну реформи» [5]. Усі аспекти секторальних реформ в умовах децентралізації розкрито на офіційному урядовому порталі [6; 7].

Виклад основного матеріалу. Саме від медіа значною мірою залежить процес упровадження секторальних реформ. Адже безпосередньо від того, наскільки доступно й незаангажовано вони доноситимуть інформацію до громадськості, залежить підтримка реформи суспільством. Тільки за умови правдивого, оперативного та цікавого висвітлення загальнонаціональними, регіональними ЗМІ, зокрема й онлайн-виданнями, усіх етапів трансформації соціальних секторів можливі якісні, вчасні та перспективні зміни в освітній, медичній, екологічній та інших галузях.

Для якісної медіації реформ потрібна тісна співпраця медіа й експертів, яка полягатиме у грунтовному поясненні і перекладі для ЗМІ «простою мовою» того, що обговорюється під час експертних дискусій. Журналістка «Радіо Свобода» Ірина Штогрін зазначає, що експерти мають обговорювати проблеми на глибинному, професійному рівні, а за підсумками цих обговорень потрібно створювати продукт, який через соцмережі може потрапити до споживачів або журналістів, у такій формі, яка $є$ максимально прийнятною для кожної з аудиторій: інтернет-аудиторії окремо, телебачення - окремо [8].

Представник телеканалів «UA: Перший» та «TV-5» (Запоріжжя) Сергій Мамаєв відзначає, що окремою проблемою $є$ робота регіональних ЗМІ. Попит на них та запит на інформацію про реформи - дуже великі, проте у регіонах бракує компетентних експертів, до яких можна звернутися за коментарем. «Найбільша проблема - некомпетентність журналістів, а взятися їй немає звідки - вони «варяться у власному соку». Їхні замовники новин, зазвичай - ОДА або власники, але не глядачі, і це також проблема», - зауважує С. Мамаєв [8].

При висвітленні соціальних реформ потрібно враховувати найдрібніші нюанси та деталі. Це питання не можна вирішити лише копіюванням медичних чи освітніх стандартів та підходів. Президент Академії української преси Валерій Іванов запропонував міні-панацею для журналістів, якою бажано керуватися при написанні матеріалів: «Враховувати позитивний та негативний досвід - це $є$ запорукою для грамотного висвітлення будь-якого питання. Мас-медіа має бути дуже обережним, коли цитує різні точки зору, підтримує ті чи інші позиції. Основна вимога до роботи журналістів - розібратися у проблемі та дати повну картину. Не слід зупинятися 
тільки на тому, що здається правильним самому журналісту. Висвітлення питання має бути з усіх можливих позицій» [10].

Мета медичної реформи - поставити пацієнтів у центрі системи охорони здоров'я та надати їм рівний доступ до якісних медпослуг. Основні положення медичної реформи полягають у: впровадженні державного гарантованого пакету медичної допомоги, створенні національної системи здоров’я України; підписанні декларацій громадян із лікарями, а лікарів та медичних закладів із НСЗУ, реорганізації медичних закладів та зміні їх юридичного статусу, переході від системи медичних субвенцій на контрактну форму оплати та впровадження принципу «гроші ходять за пацієнтом», створенні єдиної централізованої електронної системи охорони здоров'я (e-Health) та єдиної системи централізованої купівлі медичного обладнання й ліків, підтримці програми «Доступні ліки», реорганізації швидкої допомоги. Усе це має за мету знизити корумпованість медичної сфери, збільшити ефективність розподілу та використання фінансів, перевести документацію з паперового варіанту в електронний та загалом підвищити оперативність надання послуг, а також налагодити системність у діяльності медичної сфери $[4 ; 7]$.

Медична реформа складається із багатьох кроків. Ї̈̈ впровадження відбувається з 2017 року поетапно і поступово. 3 початком впровадження кожного важливого етапу медичної реформи зростає кількість медіаматеріалів на цю тему. За аналізований період зафіксовано чотири таких періоди: червень 2017 року (запрацювала електронна система eHealth), жовтень-грудень 2017 року (прийняття необхідних законопроектів), березень-травень 2018 року (кампанія з підписання декларацій з сімейними лікарями), червень-липень 2018 року (початок фінансування медичних закладів за новою системою та обслуговування тих пацієнтів, що підписали декларації, відповідно до положення).

У тернопільських інтернет-виданнях «Терен» $\mathrm{i}$ «20 хвилин» 31 березня 2017 року (поява першої інформації про суть медичної реформи) до початку 2019 року було опубліковано 76 матеріалів: «20 хвилин» - 28, «Терен» - 48 публікацій під тегами «сімейна медицина», «здоров’я», «медична реформа».

Онлайн-медіа Тернополя висвітлювали різні аспекти медичної реформи. Усі публікації можна поділити на основні тематичні групи:

- прийняття необхідних законів, нормативних актів тощо («20 хвилин»: «Президент підписав закон, що дає старт медичній реформі», 28.12.2017), а також роз'яснення їх суті («20 хвилин»: «Скільки платитимуть сімейним лікарям за немовлят, дітей, дорослих і літніх - рішення уряду», 25.04.2018) [2];

- суть медичної реформи та тих змін, що очікують пацієнтів, лікарів та медичні установи («20 хвилин»: «Після старту реформи медичні заклади фінансуватимуть по-іншому», 30.04.2017; «Медична реформа: що чекати пацієнтам 3 1 липня», 17.05.2017; «Медреформа: з чого починати тернополянам», 5.02.2018; «Терен»: «Тернополянам на замітку: що дасть медична реформа?», 16.06.2017; «Реформа крокує Тернопільщиною - лікарів уже... попередили», 13.01.2018) $[2 ; 3]$

- спростування міфів, щзо уже склалися в суспільстві щодо змін у медичній галузі («Терен»: «Чи готові тернопільські медики до цілодобового контролю?», 17.04.2017; «Лідія Чайковська: "Найбільше бояться медичної реформи - лікаpi"»», 18.11.2017) [3]; 
- укладання договорів пацієнтів із сімейними лікарями. Такі матеріали містять інформацію про етапи підписання декларацій («20 хвилин»: «Договори із сімейними лікарями будемо укладати 31 липня», 4.03.2017; «Терен»: «Тернополяни ще мають час підготуватись до медичних змін», 16.01.2018; «Медреформа в дії: батькам час обрати педіатра, - Олег Нитка», 3.04.2018), інструкцію з підписання («20 хвилин»: «Як ви обиратимете сімейного лікаря?», 10.05.2017; «Як тернополянам обрати собі сімейного лікаря», 18.11.2017; «Терен»: «Як тернополянам обрати сімейного лікаря», 2.02.2018; «Тернополяни можуть зареєструвати «стосунки» із лікарем всього за 4 хвилини», 29.04.2018) або ж реакцію та роз'яснення труднощчів, щзо виникали при укладанні договорів («20 хвилин»: «Підписати декларацію з сімейним лікарем можна при першому ж зверненні. Не варто створювати ажіотаж в понеділок», 7.04.2018; «Тернополяни скаржаться, що не можуть підписати декларації з лікарем», 11.04.2018; «Терен»: «Що буде з тернополянами, які не підпишуть договір із терапевтом», 23.11.2017); статистичну інформацію про хід підписання угод («20 хвилин»: «Сімейного лікаря обрали майже 2 тисячі тернополян...», 10.04.2018; «Угоду з сімейним лікарем уже підписали майже 285 тисяч жителів Тернопільщини», 30.06.2018; «П'ять сімейних лікарів Тернополя вже набрали необхідну кількість пацієнтів», 5.09.2018; «Тернопільщина увійшла в лідери з підписання декларацій з лікарями», 29.11.2018; «Терен»: «Лише 30\% тернополян обрали сімейного лікаря», 19.06.2018; «Скільки жителів Тернопільщини вже обрали собі сімейного лікаря?», 5.11.2018) [2; 3];

- зміни у спектрі послуг, які зобов’язаний надавати сімейний лікар («20 хвилин»: «За обстеженням й аналізами - до сімейного лікаря», 5.02.2018; «Які послуги будуть надавати сімейні лікарі, терапевти і педіатри з липня», 2.07.2018; «20 хвилин»: «Компетенція сімейного лікаря тепер значно ширша, - запевнив тернополян експерт», 27.10.2018), зміни тарифів на послуги («20 хвилин»: «За що треба платити в сімейного лікаря», 28.04.2018; «Кого примусять заплатити за прийом сімейного лікаря?», 24.09.2018; «Терен»: «Тернополяни будуть знати, за що платять у лікарнях», 22.08.2017) [2; 3];

- реорганізація швидкої та екстреної допомоги. У публікаціях цієї тематики висвітлювали як регіональні нюанси впровадження («20 хвилин»: «Як реформа змінює швидку?», 31.08.2018; «Терен»: «Реорганізації системи екстреної медичної допомоги на Тернопільщині обійшлася в 7,5 млн грн», 8.11.2017; «Жителі Тернопільщини першими в Україні випробують оновлену екстрену медичну допомогу», 11.09.2018), так і загальні стратегії («20 хвилин»: «В Україні скоротиться час доїзду бригад медиків. Незабарои почне працювати екстрена медична допомога», 12.09.2018; «Терен»: «В Тернополі готуватимуть парамедиків для всієї України», 10.11.2017; «На Тернопільщині покращать роботу швидкої допомоги», 5.12.2018) [2; 3];

- впровадження електронної системи е-Health («20 хвилин»: «Онлайн можна отримати пораду, але не консультацію. Тернопільські лікарі про лікування через соцмережі», 11.11.2018; «Терен»: «На Тернопільщини презентували електронну медицину», 19.09.2017) [2; 3];

- формування госпітальних округів («Терен»: «Окружна лікарня: як працюватиме заклад у нових умовах», 2.06.2017; «Який госпітальний округ на Тернопільщині 
найбідовіший?», 24.11.2017; «Тернопільську область поділять на чотири госпітальні округи», 30.01.2018) [3];

- опитування містян щодо їх довіри до змін у медичній галузі («20 хвилин»: «Чи обрали для себе тернополяни сімейного лікаря?», 5.11.2017; «Терен»: «Тернополяни не вірять у зміни медичної реформи», 30.01.2018) [2; 3];

- медичне страхування та його проиедура («Терен»: «Тернополянам пояснили, як оплачуватимуть медичне страхування», 14.05.2018; «Особливості страхування здоров’я для жителів Тернопільщини», 30.12.2018) [3];

У поодиноких публікаціях висвітлено питання зміни процедури ліцензування лікарів, запровадження Національної системи здоров’я України або НЗСУ, створення медичної «гарячої лінії», розподілу коштів між лікарнями, обрання місцевого керівника реформи, заробітної плати медиків (збільшення, зменшення, затримка виплат), реалізації програми «Доступні ліки». Загалом, тематичний спектр матеріалів медичного контенту в інтернет-виданнях «20 хвилин» і «Терен» доволі розмаїтий, проте можна виділити тематичні групи, представлені найширше у кількісно-якісному аспекті. Це медична реформа як система змін у медичній галузі та її найважливіші складові - підписання декларацій пацієнтів із сімейними лікарями, спектр їхніх послуг та реорганізація швидкої та екстреної допомоги. Інші елементи реформи, що не стосуються безпосередньо усього населення, висвітлювались у регіональних ЗМІ значно менше.

У публікаціях про медичну реформу журналісти посилаються на певні джерела інформації: Міністерство охорони здоров'я України (найчастіше Уляна Супрун та іiї заступник Павло Ковтонюк), лікарі (заступник головного лікаря Тернопільського міського «Центру первинної медико-санітарної допомоги» та інші медпрацівники), представники органів законодавчої та виконавчої влади (н-д, Президент, Прем'єр-міністр, КАБМІН), представники місцевої влади (н-д, начальник управління охорони здоров’я Тернопільської обласної державної адміністрації Володимир Богайчук), експерти 3 медичною чи юридичною освітою, рідше - власне реципієнти видань (обговорення у коментарях до новин, опитування «наживо»), національні ЗМІ (сайт «Терен» найчастіше посилається на портали «Сегодня», «gazeta.ua», «espreso.tv», «prefiks.win.NGO Centre UA» та ін.).

Освітня галузь стала черговим суспільним майданчиком для впровадження новітніх реформ. Освіта є основою інтелектуального, духовного, фізичного й культурного розвитку особистості, її успішної соціалізації, економічного добробуту, запорукою розвитку суспільства, об'єднаного спільними цінностями і культурою, та держави, - йдеться у Законі України «Про освіту» (головний нормативний документ реформи), прийнятому 5 вересня 2017 року [1]. Зміни, внесені до нього, почали впроваджувати на практиці з 2018 року.

Основні положення Закону України «Про освіту» стосуються фінансування системи освіти, автономності для суб'єктів навчального процесу, процедури зарахування учнів до школи, оновлення матеріально-технічної бази, зміни навчальних програм та моделі оцінювання знань, створення інклюзивного освітнього середовища, процедури підвищення кваліфікації вчителів тощо [1].

Від квітня 2017 року - часу першої публікації про реформування освіти - до початку 2019 року в обраних онлайн-виданнях опубліковано 44 матеріали (20 - на сайті «Терен» і 24 - на порталі «20 хвилин») під хештегами «освіта», «НУШ», «ре- 
форма», «Нова українська школа», «школа». Усі публікації можна поділити на основні тематичні блоки:

- суть освітньої реформи і тих змін, що очікують учителів, учнів, батьків та навчальні заклади («20 хвилин»: «Чого чекати від нового навчального року?», 13.08.2017; «Гроші, інтернет, автобус - чим до змін мотивують школи на Тернопільщині», 13.05.2018; «Терен»: «Тернопільщина: у школах і училищах готуються до грандіозних змін», 24.04.2018; «Тернопільщина 3 предметоцентризму переходить на дітоцентризм», 10.05.2018; «Головна освітянка Тернопільщини провела перед журналістами урок», 6.07.2018; «На освіту Тернопільщини чекають зміни», 23.08.2018; «Коли чекати змін в освіті, та що для цього робити?» 31.08.2018) [2; 3];

- закриття малоформатних шкіл, побудова нових шкіл та створення сітки опорних закладів в області («20 хвилин»: «На Тернопільщині ще є школи, де навчаються троє дітей», 26.04.2017; «Школа має дати учням не знання, а компетентності. Директор опорної школи про освітню реформу», 6.07.2018; «На Тернопільщині ліквідували дев’ять шкіл, ще шість - понизили у ступені», 29.08.2018; «Терен»: «Міністр сказав, у якій сфері Тернопільщина вибилася в лідери», 26.04.2018; «В селі на Тернопільщини збудують школу з ліфтом та лабораторіями», 29.12.2018) [2; 3];

- нові правила зарахування до шкіл («20 хвилин»: «У Тернополі більше не буде спеціалізованих шкіл, а учнів набиратимуть за пропискою», 18.02.2018; «I в садки, і в школи тепер братимуть тільки 3 довідкою про місце проживання», 12.05.2018; «Школа за місцем реєстрації: що чекає на батьків першокласників», 21.05.2018) [2];

- впровадження реформи в початковій освіті («20 хвилин»: «Зошитів та ручок тепер у перший клас непотрібно», 18.08.2018; «Першачки області місяць не матимуть підручників для навчання», 30.08.2018; «Терен»: «Тернопільським першачкам обіцяють уроки на вулиці та тематичні дні», 6.07.2017; «Перші класи у школах Тернопільщини не впізнають», 20.04.2018) [2; 3];

- взаємовідносини між учнями та вчителями («20 хвилин»: «Вчитель має бути таким, як діти. Головна освітянка області розповіла про нові вимоги до вчителів та учнів», 5.07.2018; «Терен»: «Тернополянам розповіли про справжнього вчителя нового століття», 25.06.2018; «Тернопільські учні чекають на вчителів-фасилітаторів», 26.11.2018) [2; 3];

- фінансування та управління загальноосвітніх закладів («Терен»: «На освіту в Тернополі витратять більше», 19.04.2018; «На Тернопільщині освітніх експертів отримали не усі ОТГ», 18.11.2018) [3];

- аспекти матеріально-технічного оснащення шкіл («20 хвилин»: «Не всі первачки у вересні сядуть за нові парти», 5.08.2018; «Нова Українська Школа без нових парт для первачків», 1.09.2018; «Чи отримали тернопільські школи парти і підручники для першокласників», 9.10.2018; «Парти в очі не бачили: до кінця жовтня 95\% шкіл мали отримати столи-трансформери», 20.10.2018; «Чому в Тернополі батьки першокласників просять забрати з класу новенькі парти», 12.11.2018) [2]; 
- вироблення чіткої системи внутрішнього $і$ зовнішнього контролю за наданням освітніх послуг («Терен»: «Революція» в освіті: чого чекати учителям і учням, розповів у Тернополі Юрій Рашкевич», 21.07.2017) [3];

- нова система підвищення кваліфікації вчителів - сертифікація («Терен»: «Тернопільські вчителі навчатимуться за кошти держави», 18.12.2017; «Масовий страх та списування. Напевно, вчителям з Тернопільщини це не притаманне», 13.02.2018) [3];

- питання заробітної плати вчителів: збільшення, зменшення, затримка виплат («Терен»: «Кращі тернопільські вчителі отримуватимуть більшу надбавку», 8.11.2017) [3];

- розвиток інклюзивної форми навчання виступає важливою задекларованою складовою реформування національної освітньої системи. Проте, незважаючи на актуальність та важливість цього питання, його майже не розкривають журналісти онлайн-медіа «Терен» і «20 хвилин». Упродовж 2018 року обидва інтернет-видання представили поодинокі матеріали відповідної проблеми. Однак інформаційним приводом написання публікацій послужили не окремі факти прикладів інклюзивної освіти в регіоні, а приїзд Марини Порошенко до Тернополя та підписання нею Меморандуму про долучення області до проекту Фонду Порошенка «Інклюзивна освіта - рівень свідомості нації»: «На Тернопільщині з робочим візитом перебуває дружина Президента України Марина Порошенко» («Терен», 19.06.2018), «Інклюзивно-ресурсний центр та медіатеку для особливих діток створять на Тернопільщині» («20 хвилин», 20.06.2018). Подібну тенденцію увиразнюють тернопільські експрес-новини «Терен», пропонуючи аудиторії інформацію про створення інклюзивних гуртків у дитячих клубах Львова (16.01.2018), відкриття інклюзивно-ресурсного центру у Зборові $(6.11 .2018)[2 ; 3]$.

Журналісти тернопільських інтернет-видань «20 хвилин» і «Терен», висвітлюючи втілення освітньої реформи, апелювали до різних джерел інформації - не тільки представників влади (Міністр освіти і науки України Лілія Гриневич, заступник Міністра освіти і науки України Юрій Рашкевич, начальник управління освіти і науки міськради Тернополя Ольга Похиляк, начальник управління освіти і науки ТОДА Ольга Хома, голова Тернопільської ОДА Степан Барна), а й безпосередніх учасників навчального процесу, які зіткнулися із реформою значно ближче, - вчителів, директорів.

Висновки. 3 початку анонсування суспільних реформ засоби масової інформації, зокрема й регіональні, почали висвітлювати найбільш обговорювані серед громадськості зміни у медичній та освітній галузях. На Тернопільщині дану тематику найактивніше розробляють онлайн-видання «Терен» $\mathrm{i}$ «20 хвилин». Медичний контент регіональних медіа відтворює поетапний процес модернізації медичної галузі та увиразнює її ключові проблеми. Освітній сегмент змістового наповнення онлайн-платформ презентує окремі аспекти реформування української освіти, які часто актуалізуються під впливом певного інформаційного приводу. Інтернет-видання «20 хвилин» пропонує проблемні матеріали, що ілюструють освітні нововведення на прикладі конкретних навчальних закладів.

Перспективи дослідження медіації секторальних реформ в Україні полягають у можливості подальшого вивчення регіонального онлайн-простору щодо висвітлен- 
ня реформування медичної та освітньої галузей в контексті соціальної парадигми сучасного медіаконтенту, аналізу структурно-композиційного та жанрового аспектів публікацій, рівня та якості поінформованості населення щодо процесу реформування медицини й освіти, а також вироблення рекомендацій щодо інформаційного супроводу реалізації суспільних реформ.

\section{REFERENCES}

1. Закон України «Про освіту» // Відомості Верховної Ради. 2017. № 38-39. [Електронний ресурс]. Режим доступу : https://zakon3.rada.gov.ua/laws/show/2145-19/page

2. Інтернет-видання «20 хвилин». [Електронний ресурс]. Режим доступу : https:// te.20minut.ua/

3. Інтернет-видання «Терен». [Електронний ресурс]. Режим доступу : https:// teren. in.ua/

4. Медична реформа. Міністерство охорони здоров'я України. [Електронний ресурс]. Режим доступу : http://moz.gov.ua/plan-reform

5. Міфи та правда про освітню та медичну реформи. Практичний посібник для журналістів / Заг. ред.: В. Таран. Київ: Центр політичних студій та аналітики «Ейдос», 2018. $88 \mathrm{c}$.

6. Реформа освіти та науки // Урядовий портал. [Електронний ресурс]. Режим доступу : https://www.kmu.gov.ua/ua/diyalnist/reformi/reforma-osviti

7. Реформа системи охорони здоров’я // Урядовий портал. Режим доступу : https:// www.kmu.gov.ua/ua/diyalnist/reformi/reforma-sistemi-ohoroni-zdorovya

8. Реформи і ЗМI: більше співпраці з експертами, більше ініціативи, більше професійності. Український кризовий медіа-центр. [Електронний ресурс]. Режим доступу : http://uacrisis.org/ua/55860-komunikatsiyi-reform

9. Чулівська І. Висвітлення реформ в медіа: хто пише прес-релізи - той замовляє музику / І. Чулівська // Інститут масової інформації. 2017. [Електронний ресурс]. Режим доступу : http://imi.org.ua/monitorings/vysvitlennya-reform-v-media-hto-pyshepres-relizy-toj-zamovlyaje-muzyku/

10. Як правильно писати про зміни в освітньому просторі. Академія української преси. [Електронний ресурс]. Режим доступу : http://www.aup.com.ua/yak-pravilnopisati-pro-zmini-v-osvitn/ 


\title{
SOCIAL REFORMS IN TERNOPIL ONLINE EDITIONS OF «TEREN» AND «20 KHVYLYN»: MEDICAL AND EDUCATIONAL TOPICS
}

\author{
Oksana Kushnir \\ Ternopil Volodymyr Hnatiuk National Pedagogical University \\ 2 Maxyma Kryvonosa str., 46027, Ternopil, Ukraine \\ e-mail: oksanakush8@gmail.com \\ https://orcid.org/0000-0003-3201-5285
}

The paper deals with the actual problem of Ukrainian journalism - the search for a new methodology that is adequate to the challenges of the time, taking into account the interaction between media and society. The issue of the correlation of national and gender identities was relevant in the Western Ukrainian society of the interwar period.

The problem of the interaction of gender and national identities should be analyzed as a question of colonialism, nation and gender in the context of the Ukrainian history of the 1920s-1930s. In addition, the national discourse with its ideology of devoted service to the people and state-building intentions was a decisive factor for the interwar generation in the conditions of the occupation of Ukraine.

The most adequate scientific method of studying this problem is the discourse analysis. Discourse analysis studies identity as a means of defining a particular group, as well as the representation of this group in the struggle for hegemony in ideological discourses. Therefore, study the Western Ukrainian press of the 1920s-1930s (for example, the popular Galician, Bukovinian and Transcarpathian periodicals) through the prism of modern approaches discourse analysis and gender analysis - is proposed in the paper. The discourse representations of femininity are explored in the ideological context of the national-democratic press. It turns out that the media space of the Western Ukrainian press was the scene of the struggle for the hegemony of two ideological discourses, patriarchal and feminist. Feminist discourse is represented by publications by the members of the Union of Ukrainian Women on the pages of popular periodicals. In these publications, the «taboo» issues of feminine identity were articulated, which was perceived as a threat to traditions and violations of public order, since authors thus redefined the social world. Significant progress has been made in the feminist aspirations of Ukrainian women and, accordingly, the fact that patriarchal ideology lost its monopoly status in the national-democratic press.

Key words: discourse, ideological discourse, discourse analysis, identity, gender. 